\title{
Study on distribution characteristics of chromium and nickel in root soils around a typical abandoned alunite mining area
}

\author{
Zhu Lin ${ }^{1,2}$, and Chen Bingyu ${ }^{1,2, *}$ \\ ${ }^{1}$ Anhui Jianzhu University, 230601 Hefei, China \\ ${ }^{2}$ Key Laboratory of Huizhou Architecture in Anhui Province, 230601 Hefei, China
}

\begin{abstract}
The exploitation of alunite resources results in the exposure of heavy metals to the surface surrounding, enrichment in soil and potential health risks to human beings. This study investigated the heavy metal pollution of root soils in a mining district surrounding a typical abandoned alunite mining area in Anhui province of China. Up to 10 root soil samples were collected in 20 sampling sites, and the concentration of $\mathrm{Cr}$ and $\mathrm{Ni}$ were determined. The results show that the root soils contained acceptable levels of $\mathrm{Cr}$ and $\mathrm{Ni}$ occurring in the ranges of 46.2-503.5 and 12.8-44 mg/kg, respectively. According to the National Soil Environment Quality Standards, few samples had $\mathrm{Cr}$ and Ni contents exceeding the risk screening values. However, due to the regional differences of background values, the geoaccumulation indices of $\mathrm{Cr}$ indicate slightly to extremely contaminated. Based on the calculation of potential ecological risk index, all the root samples were considered as low health risk level. These findings indicate the possible need for deeply and comprehensively investigation of heavy metals at alunite ore mines.
\end{abstract}

\section{Introduction}

Heavy metal pollution has been considered as one of the most important contaminations in soils. There are several routes which can accelerate the enrichment of heavy metals contents, included natural processes and anthropogenic activities ${ }^{[1]}$. Furthermore, heavy metals released from mining activities generally can be transported to soils surrounding, accumulated in plants and animals, and finally affected human health through food chain ${ }^{[2]}$. These issues would be clearly magnified if mines were abandoned without any management measure.

Alunite mining activities in Lujiang County, Anhui Province, were actively developed from the early twentieth century, but all of the mines had been closed gradually until the beginning of this century due to development policies and the exhaustion of alunite reserves. The rock structure was slightly destroyed with fracture network increasing, while a large amount of accumulated slag would cause serious harm to the surrounding environment. Thus, all of these changes could indirectly enhance the occurrence probability of secondary geological disasters in rainfall season, such as slope collapse, landslide and debris flow.

Compared with mining activities, the exploitation of alunite resources could more easily generate acid-mine drainage (AMD), based on the ionization of alunite ore and the oxidation of accompanying pyrite ${ }^{[3]}$. This feature further facilitates the soil heavy metal pollution in the alunite mining area.

In this study, contamination level and risk assessment of $\mathrm{Cr}$ and $\mathrm{Ni}$ in a typical abandoned alunite mine were investigated. Based on the research results, remediation strategies for the studied mine were also provided.

\section{Materials and methods}

\subsection{Sampling and analysis}

Dominant plant and corresponding root soil samples were collected around the abandoned alunite mine (Fig. 1). About 15 varieties of local dominant plants in 20 sampling sites were taken, and carefully washed with deionized water to remove soil particles or dust adhered to the plant surface. The whole plant collection method was adopted, while 3 to 5 samples for each plant were randomly selected. Samples were then air-dried at $70{ }^{\circ} \mathrm{C}$ for $72 \mathrm{~h}$. The dry samples were crushed and digested with a mixed solution $\left(\mathrm{HNO}_{3}: \mathrm{H}_{2} \mathrm{O}_{2}=8: 2\right)$ for subsequent analyzation.

The corresponding soil samples were also collected by plum blossom method. After being naturally air-dried and making sure that debris, animal and plant residues and other impurities had been removed, soil samples were sieved through a 200-mesh nylon sieve. In order to determine the concentrations of $\mathrm{Cr}$ and $\mathrm{Ni}$, the root soil samples $(\sim 0.2 \mathrm{~g})$ were fully digested with mixed acids $\left(\mathrm{HNO}_{3}: \mathrm{HCl}: \mathrm{HF}=3: 1: 1\right)$ in a microwave digestion instrument (Multiwave 3000, Anton Paar GmbH). Two heavy metals in all the samples, $\mathrm{Cr}$ and $\mathrm{Ni}$, being focused on in this study, were analyzed by a X Series 2 Inductively Coupled Plasma-Mass Spectrometer (Thermo fisher

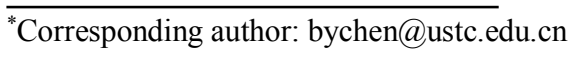


Scientific, USA). The uncertainties for $\mathrm{Cr}$ and $\mathrm{Ni}$ determined, were within $5 \%$.

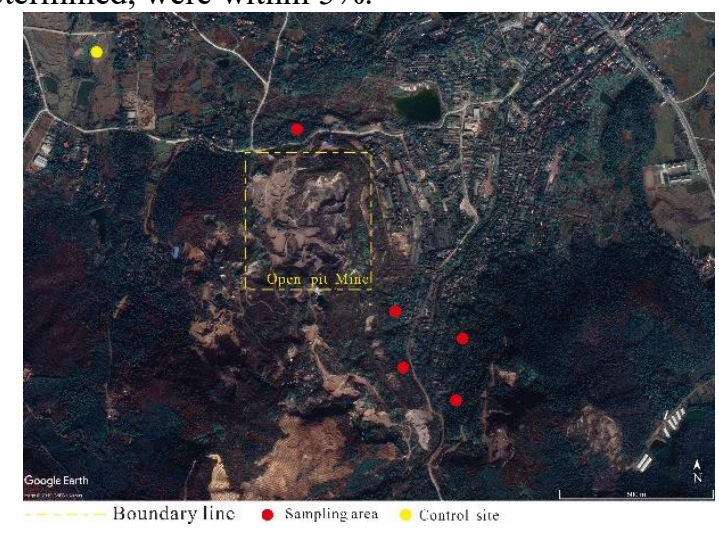

Fig. 1. The schematic diagram of sampling distribution.

\subsection{Data analysis}

The geoaccumulation index was identified by Muller [4] and adopted in this study. Hence, the $I_{g e o}$ equation was used as:

$$
I_{g e o}=\log _{2} \frac{C_{i}}{1.5 C_{0}}
$$

where $C_{\mathrm{i}}$ is the measured concentration $(\mathrm{mg} / \mathrm{kg})$ of $\mathrm{Cr}$ and $\mathrm{Ni}$ in soil, and $C_{0}$ is the background concentration of $\mathrm{Cr}$ and $\mathrm{Ni}$ in the soils of Anhui Province ${ }^{[5]}$. The 1.5 constant was used to correct for regional background difference. The contamination could be divided into 6 levels: uncontaminated $\left(I_{\text {geo }} \leq 0\right)$, slightly contaminated $\left(0<I_{\text {geo }}<1\right)$, moderately contaminated $\left(1<I_{\text {geo }}<2\right)$, moderately to heavily contaminated $\left(2<I_{g e o}<3\right)$, heavily contaminated $\left(3<I_{\text {geo }}<4\right)$, heavily to extremely contaminated $\left(4<I_{\text {geo }}<5\right)$, and extremely contaminated $\left(5 \leq I_{\text {geo }}\right)^{[6]}$.

The potential ecological risk assessment was employed by calculating the potential ecological risk index $(R I)$ of $\mathrm{Cr}$ and $\mathrm{Ni}$ in the soils surrounding the alunite mining area ${ }^{[7,8]}$. The following formula was applied for the calculation of $R I$ :

$$
\begin{gathered}
C_{r}^{i}=\frac{C_{i}}{C_{0}} \\
E_{r}^{i}=T_{r} \times C_{r}^{i} \\
R I=E_{C r}^{i}+E_{P b}^{i}
\end{gathered}
$$

where $C_{r}^{i}$ is the enrichment coefficient of heavy metal $(\mathrm{Cr}$ and $\mathrm{Ni}$ in this study) in soil, $E_{r}^{i}$ is the potential ecological risk factor of single element, and $T_{r}$ is the toxic-response coefficient whose values are 2 and 5 for $\mathrm{Cr}$ and $\mathrm{Ni}$, respectively ${ }^{[7]}$. The potential ecological risk of heavy metals in soils could be classified into five categories based on the values of $E_{r}^{i}$ and $R I$, as detailed in Table 1 .

The ability of dominant plants to accumulate heavy metals was expressed by transportation and enrichment coefficients, while transportation coefficient was obtained by the ratio of the heavy metal content in the aboveground part and the value in the underground part, and enrichment coefficient equals the ratio of the heavy metal content between in the aboveground part and in the root soil.
Table 1. Grading standards of potential ecological risk of heavy metal pollution.

\begin{tabular}{|c|c|c|}
\hline $\begin{array}{c}\text { Risk factor for } \\
\text { single metal }\end{array}$ & $\begin{array}{c}\text { Risk index for } \\
\text { multiple metals }\end{array}$ & $\begin{array}{c}\text { Ecological risk } \\
\text { level }\end{array}$ \\
\hline$<40$ & 150 & Low \\
\hline $40-80$ & $150-300$ & Moderate \\
\hline $80-160$ & $300-600$ & Considerable \\
\hline $160-320$ & $600-1200$ & High \\
\hline$>320$ & $>1200$ & Very high \\
\hline
\end{tabular}

\section{Results and discussion}

Table 2 summarizes the distribution characteristics of $\mathrm{Cr}$ and $\mathrm{Ni}$ in sampling root soils. The ranges of soil $\mathrm{Cr}$ and $\mathrm{Ni}$ contents are 46.20-503.50 and $12.80-44.00 \mathrm{mg} / \mathrm{kg}$, respectively. Compared with their background values, it is identified that mining activities significantly raise the releasing content of heavy metal from alunite mining area into soils surrounding. However, due to the specific element composition of alunite ore, the $\mathrm{Cr}$ and $\mathrm{Ni}$ pollution is not as serious as expected. According to GB 15618-2018 (National Soil Environmental Quality Criterion, China), $\mathrm{Cr}$ and $\mathrm{Ni}$ contents in few sampling

\begin{tabular}{|c|c|c|c|c|}
\hline HMs & Max & Min & $\begin{array}{c}\text { Background } \\
\text { Value }^{\mathrm{a}}\end{array}$ & $\begin{array}{c}\text { Screening } \\
\text { Value }^{b}\end{array}$ \\
\hline $\mathrm{Cr}$ & 503.50 & 46.20 & 66.50 & 250.00 \\
\hline $\mathrm{Ni}$ & 44.00 & 12.80 & 29.80 & 60.00 \\
\hline
\end{tabular}
soils exceed the corresponding risk screening value.

Table 2. The distribution characteristics of $\mathrm{Cr}$ and $\mathrm{Ni}$ in sampling root soils $(\mathrm{mg} / \mathrm{kg})$.

${ }^{a}$ Corresponding heavy metal background values of Anhui Province ${ }^{[5]}$

${ }^{\mathrm{b}}$ Risk screening values $(\mathrm{pH} \leq 5.5)$ according to National Soil Environmental Quality Standards, China (GB 15618-2018)

Table 3 summarizes the geoaccumulation index and potential risk index of heavy metals in the root soils surrounding the mining district. The root soils were slightly to extremely polluted with respect to $\mathrm{Cr}$ based on the $I_{\text {geo }}$ values, while there is significant differentiation of $\mathrm{Cr}$ pollution in the studied root soils. Meanwhile, the root soils were only slightly contaminated with respect to $\mathrm{Ni}$, corresponding to the lower concentrations than screening value.

Although the geoaccumulation index of $\mathrm{Cr}$ reveals a certain pollution phenomenon, $\mathrm{Cr}$ posed the acceptable level of potential ecological risk with $E_{C r}^{i}$ values significantly lower than 40 . Similarly, Ni had single risk indices below 40, which are indicative of low risk. The $R I$ values suggest than $\mathrm{Cr}$ and $\mathrm{Ni}$ in the root soils surrounding the typical alunite mining area had negligible potential ecological risk. This positive situation is probably caused by long-term non-exploitation and that chromium and nickel are unimportant constitute to the alunite ore. 
Table 3. Geoaccumulation index and Potential risk index of soil $\mathrm{Cr}$ and $\mathrm{Ni}$.

\begin{tabular}{|c|c|c|c|c|c|}
\hline \multirow{2}{*}{ Plant Category } & \multicolumn{2}{|c|}{ Igeo } & \multicolumn{2}{|c|}{$E_{r}^{i}$} & \multirow{2}{*}{$R I$} \\
\hline & $\mathrm{Cr}$ & $\mathrm{Ni}$ & $\mathrm{Cr}$ & $\mathrm{Ni}$ & \\
\hline $\begin{array}{c}\text { control site } \\
\text { (agricultural land) }\end{array}$ & 0.70 & 0.65 & 2.11 & 4.87 & 6.98 \\
\hline $\begin{array}{c}\text { Ophiopogon } \\
\text { bodinieri Levl }\end{array}$ & 0.75 & 0.29 & 2.24 & 2.15 & 4.39 \\
\hline $\begin{array}{c}\text { Lysimachia fortune } \\
\text { Maxim }\end{array}$ & 0.51 & 0.42 & 1.53 & 3.15 & 4.68 \\
\hline Bidens pilosa $L$ & 5.05 & 0.98 & 15.14 & 7.38 & 22.52 \\
\hline $\begin{array}{l}\text { Haloragis micrantha } \\
\text { (Thunb.) } R . B r\end{array}$ & 0.46 & 0.34 & 1.39 & 2.58 & 3.97 \\
\hline $\begin{array}{l}\text { Conyza canadensis } \\
\text { (L.) Cronq }\end{array}$ & 0.61 & 0.60 & 1.82 & 4.53 & 6.35 \\
\hline $\begin{array}{l}\text { Pteridium aquilinum } \\
\text { (L.) Kuhn var }\end{array}$ & 0.69 & 0.61 & 2.07 & 4.60 & 6.67 \\
\hline $\begin{array}{l}\text { Schisandra chinensis } \\
\text { (Turcz.) Baill }\end{array}$ & 1.34 & 0.67 & 4.02 & 5.03 & 9.05 \\
\hline $\begin{array}{c}\text { Phytolacca acinosa } \\
\text { Roxb }\end{array}$ & 1.73 & 0.86 & 5.20 & 6.46 & 11.66 \\
\hline $\begin{array}{l}\text { Commelina } \\
\text { communis L }\end{array}$ & 2.45 & 0.98 & 7.36 & 7.37 & 14.73 \\
\hline Viola philippica & 1.39 & 0.65 & 4.17 & 4.87 & 9.04 \\
\hline
\end{tabular}

Table 4. Enrichment and transportation coefficient of dominant plants.

\begin{tabular}{|c|c|c|}
\hline \multirow{2}{*}{ Plant Category } & \multicolumn{2}{|c|}{ Cr } \\
\cline { 2 - 3 } & $\begin{array}{c}\text { Enrichment } \\
\text { Coefficient }\end{array}$ & $\begin{array}{c}\text { Transportation } \\
\text { Coefficient }\end{array}$ \\
\hline Ophiopogon bodinieri Levl & 0.16 & 2.86 \\
\hline Lysimachia fortune Maxim & 0.07 & 0.86 \\
\hline $\begin{array}{c}\text { Bidens pilosa L } \\
\text { Haloragis micrantha } \\
\text { (Thunb.) R. Br }\end{array}$ & 0.15 & 1.52 \\
\hline $\begin{array}{c}\text { Conyza canadensis (L.) } \\
\text { Cronq }\end{array}$ & $\mathrm{nd}$ & 0.80 \\
\hline $\begin{array}{c}\text { Pteridium aquilinum (L.) } \\
\text { Kuhn var }\end{array}$ & 0.04 & 0.88 \\
\hline $\begin{array}{c}\text { Schisandra chinensis } \\
\text { (Turcz.) Baill }\end{array}$ & 0.02 & 1.00 \\
\hline $\begin{array}{c}\text { Phytolacca acinosa Roxb } \\
\text { Commelina communis L }\end{array}$ & 0.01 & 0.56 \\
\hline $\begin{array}{c}\text { Viola philippica } \\
\text { Thy }\end{array}$ & 0.03 & 0.62 \\
\hline
\end{tabular}

nd represents not detectable

As one of the most important remediation methods, phytoremediation is mainly according to the absorption mechanism of dominant plants to heavy metals in the root soil. Hence, the enrichment coefficient and transportation coefficient were used to characterize the absorption and transportation capacity of dominant plants to $\mathrm{Cr}$ in the alunite mining area, which has obviously potential ecological health risk. Table 4 summarizes the calculation results of enrichment and transportation coefficient of dominant plants, based on the determination of $\mathrm{Cr}$ contents in the overground and underground parts of dominant plants. The enrichment coefficients of dominant plants to $\mathrm{Cr}$ were significantly low, suggested that the ability of dominant plants to accumulate $\mathrm{Cr}$ in the studied area was not apparent. However, some typical plants such as Ophiopogon bodinieri Levl, Haloragis micrantha (Thunb.) R. Br, Schisandra chinensis (Turcz.) Baill, and Commelina communis L, posed relatively high transportation coefficients, given the opportunity to become part of satisfactory combined remediation.

\section{Conclusions}

The abandoned alunite mine had relatively high levels of $\mathrm{Cr}$ and $\mathrm{Ni}$ with respect to background values, while the heavy metal contents are still within the limits of national risk screening values. The accumulation index and potential ecological risk index were calculated, and the result shows that the root soils surrounding the abandoned alunite mining area were not seriously polluted with respect to $\mathrm{Cr}$ and Ni. However, different levels of $\mathrm{Cr}$ pollution had been identified by the geoaccumulation index, although the single risk index of $\mathrm{Cr}$ and the comprehensive potential ecological risk index $R I$ are indicative of low risk. Without the regional influence, it can be concluded that alunite mining activities contribute few $\mathrm{Cr}$ and Ni to soils surrounding, caused that this typical alunite mining area had been abandoned for a long time and the mineral composition of alunite ore contain low levels of $\mathrm{Cr}$ and Ni. Plants such as Ophiopogon bodinieri Levl, Haloragis micrantha (Thunb.) R. Br, Schisandra chinensis (Turcz.) Baill, and Commelina communis L, could be better choices in the consequent remediation of heavy metal pollution.

\section{Acknowledgement}

This work was supported in parts by the Initial Foundation for Introduce Talents and Doctors of Anhui Jianzhu University (Grant No. 2018QD37), the Natural Science Foundation of Universities of Anhui Province (Grant No. KJ2019A0759), the Science and Technology Major projects of Anhui Province (Grant Nos. 18030801106, 16030801118), and the Key Research and Development Plan of Anhui Province (Grant No. 201904a07020070).

\section{References}

1. R. Juncos, M. Arcagni, S. Squadrone.,. Ecotox. Environ. Safe. 168, 431-442 (2019)

2. M.C. Jung. Appl. Geochem. 16, 1369-1375 (2001)

3. I. Park, C.B. Tabelin, S. Jeon, X. Li, K. Seno, M. Ito, N. Hiroyoshi. Chemosphere. 219, 588-606 (2019)

4. G. Muller. Geojournal. 2, 109-118 (1969) 
5. China National Environmental Monitoring Centre. The soil background value in China. (1990)

6. L. Dai, L. Wang, T. Liang, T. Zhang, Y. Ma, C. Xing, B. Xing. Sci. Total. Environ. 621, 1433-1444 (2018)

7. L. Hakanson. Water Res. 14, 975-1001 (1980)

8. G. Suresh, V. Ramasamy, V. Meenakshisundaram, R. Venkatachalapathy, V. Ponnusamy. Appl. Radiat. Isotopes. 69, 1466-1474 (2011) 